\title{
PENERAPAN PENDEKATAN MATEMATIKA REALISTIK UNTUK MENINGKATKAN KEMAMPUAN OPERASI HITUNG PERKALIAN
}

\author{
Sarniyati Yusmanita ${ }^{1}$, M. Ikhsan ${ }^{2}$, Cut Morina Zubainur ${ }^{3}$ \\ ${ }^{1}$ Magister Pendidikan Matematika Program Pascasarjana Universitas Syiah Kuala Banda Aceh \\ ${ }^{2,3}$ Fakultas Keguruan dan Ilmu Pendidikan Matematika Universitas Syiah Kuala Banda Aceh \\ utedh@yahoo.com
}

\begin{abstract}
Abstrak
Penelitian ini dilakukan untuk mengetahui aktivitas, hasil belajar, dan respon siswa terhadap pembelajaran dengan menggunakan pendekatan Pendidikan Matematika Realistik (PMR) pada materi operasi hitung perkalian. Penelitian ini merupakan Penelitian Tindakan Kelas (Classroom Action Research) yang dilakukan sebanyak tiga siklus. Subjek penelitian yaitu 33(tiga puluh tiga) siswa kelas IV SD Negeri 46 Banda Aceh. Pengumpulan data dilakukan dengan menggunakan tes formatif hasil belajar siswa, lembar observasi aktivitas siswa, dan angket respon siswa. Hasil penelitian menunjukkan bahwa aktivitas siswa yang diharapkan dalam pembelajaran terdapat peningkatan dengan menggunakan pendekatan PMR pada materi operasi hitung perkalian di kelas IV SD Negeri 46 Banda Aceh. Siklus-I terdapat $40 \%$ aktivitas siswa yang aktif, siklus-II terdapat $80 \%$ aktivitas siswa yang aktif, dan pada siklus-III $100 \%$ aktivitas siswa aktif. Selanjutnya juga terdapat peningkatan kemampuan operasi hitung perkalian siswa pada setiap siklus. Siklus-I terdapat 33,3\% tuntas, siklus-II terdapat 63,6\% tuntas, dan siklus-III terdapat 96,97\% tuntas. Respon siswa juga sangat positif terhadap pembelajaran dengan menggunakan pendekatan PMR pada materi operasi hitung perkalian di kelas IV SD Negeri 46 Banda Aceh.
\end{abstract}

Kata kunci: Pendekatan pendidikan matematika realistik, kemampuan operasi hitung perkalian

\begin{abstract}
This research was conducted to know the activity, learning result, and student's response to learning using Realistic Mathematics Education (RME) approach on multiplication counting material. This research is a Classroom Action Research which carried out three cycles. The subjects were 33 fourth grade students of SD Negeri 46 Banda Aceh. Data collection was done by using formative test of student learning result, student activity observation sheet, and student response questionnaire. The results showed that the expected student activity in the learning process was improved by using RME approach on multiplication counting material in class IV SD Negeri 46 Banda Aceh. There are $40 \%$ of active student activity, the second cycle is $80 \%$ active student activity, and in $100 \%$ cycle $100 \%$ active student activity. Furthermore there is also an increase in the ability of student counting operations multiplication in each cycle. The cycle-I is $33.3 \%$ complete, the IIcycle is $63.6 \%$ complete, and the III-cycle is $96.97 \%$ complete. Student response is also very positive on the learning by using PMR approach on the material of multiplication operation in class IV SD Negeri 46 Banda Aceh.
\end{abstract}

Keywords: realistic mathematics Education approach, multiplication counting ability 


\section{PENDAHULUAN}

Matematika merupakan salah satu bagian dari pendidikan yang dapat melatih siswa untuk berpikir kritis. Hal ini seperti yang ditegaskan oleh Depdiknas (2006) bahwa salah satu standar kompetensi lulusan mata pelajaran matematika untuk satuan pendidikan dasar hingga menengah, agar siswa memiliki kemampuan berpikir logis, analitis, sistematis, kritis dan kreatif serta kemampuan bekerjasama. Namun, tercapai atau tidaknya tujuan pembelajaran matematika salah satunya dapat dilihat dari keberhasilan siswa dalam memahami matematika dan memanfaatkannya untuk menyelesaikan persoalan-persoalan matematika maupun ilmuilmu yang lainnya.

Matematika merupakan salah satu pelajaran yang penting di Sekolah Dasar (SD) dan diperkenalkan sejak siswa menginjak belajar di SD. Tujuan pembelajaran matematika di SD menurut Permendiknas nomor 22 tahun 2006 adalah untuk melatih cara berpikir dan bernalar dalam menarik kesimpulan, mengembangkan aktivitas kreatif, mengembangkan kemampuan memecahkan masalah, dan mengembangkan kemampuan menyampaikan informasi atau mengkomunikasikan gagasan. Pembelajaran matematika di SD juga mengharapkan siswa mampu menemukan sendiri berbagai pengetahuan yang diperlukannya saat proses belajar mengajar dilakukan. Menurut Heruman (2007), setiap konsep yang abstrak atau yang baru dipahami siswa, guru perlu memberi penguatan agar pembelajarannya mengendap dan tersimpan di memori siswa. Akibatnya diperlukan adanya pembelajaran melalui perbuatan dan pengertian, tidak hanya sekedar hafalan saja atau melihat fakta saja, karena akan mudah dilupakan oleh siswa, terutama siswa di sekolah dasar yang masih berpikir secara kongkrit.

Salah satu materi yang telah diperkenalkan kepada para siswa ketika mereka menginjak kelas II SD/MI adalah perkalian. Perkalian dengan hasil bilangan dua angka merupakan kompetensi dasar baru bagi peserta didik kelas II SD/MI dan konsep perkalian ditanamkan sebagai penjumlahan berulang. Kemampuan dasar berhitung perkalian dua bilangan 1-10 perlu dikuasai siswa sejak kelas II. Hal ini karena penguasaan materi perkalian ini merupakan bekal prasyarat untuk mempelajari materi berhitung selanjutnya. Pada jenjang ini, para siswa dituntut untuk segera menguasai konsep perkalian dan pembagian terlebih dahulu agar lebih mudah bagi siswa dalam memahami materi selanjutnya. Hudojo (1990:4) juga mengatakan bahwa "mempelajari konsep B yang berdasarkan konsep A, maka siswa perlu memahami lebih dulu konsep A, karena tanpa memahami konsep A tidak mungkin siswa memahami konsep B"

Namun, pada kenyataannya siswa sulit mempelajari materi-materi tertentu di kelas tinggi dikarenakan pemahaman siswa terhadap materi perkalian masih kurang. Rendahnya pemahaman siswa terhadap konsep perkalian juga ditemukan dalam penelitian Saahi, 
Ismaimuza, Idris (2015) dan Nilakusumawati (2014). Hal ini juga peneliti temukan pada siswa kelas IV SD Negeri 46 Banda Aceh yang sebagian besar masih terkendala dengan konsep perkalian dan berdasarkan hasil analisis ulangan harian yang pernah peneliti lakukan, juga menemukan setidaknya empat hal yang mengakibatkan mengapa matematika di kelas tinggi terasa sulit. Pertama, pemahaman siswa terhadap materi perkalian masih kurang. Kedua, sebagian siswa tidak mampu mengawali dari mana untuk menemukan jawaban. Ketiga, siswa terkadang lupa dengan aturan-aturan matematis, dan terkadang terjebak dengan syarat-syarat yang harus dikuasai lebih dahulu seperti memahami perkalian. Keempat, ada kecenderungan siswa mengerjakan soal dengan satu cara saja, tidak kreatif dalam mencari cara baru.

Berdasarkan hasil analisis ulangan harian siswa di atas, sangat diperlukan suatu tindakan untuk mengatasi masalah yang dihadapi oleh siswa tersebut terutama pada pemahaman terhadap konsep perkalian yang merupakan materi esensial dan prasyarat untuk materi yang lainnya. Akibatnya seorang guru perlu berusaha membuat pembelajaran matematika menjadi lebih menyenangkan. Salah satu hal yang dapat membuat siswa-siswa senang dengan matematika adalah kebebasan mereka bereksperimen dengan matematika tersebut. Persoalan matematika yang sering dihadapi anak adalah sering kali anak kurang terampil mengoperasikan aritmatika. Walaupun mereka mampu, kebanyakan dari mereka kurang cepat dan tepat untuk menyelesaikan persoalan mengalikan angka. Menurut Muslimin (2012), hal ini terjadi karena guru kurang memberi motivasi pada siswa untuk menyukai pelajaran matematika, pendekatan dan media yang digunakan guru juga kurang bervariasi dan menarik. Padahal seorang guru dituntut supaya lebih kreatif dan inovatif dalam menciptakan pembelajaran yang menyenangkan. Terutama pembelajaran matematika di SD yang merupakan tahap penanaman konsep dan perkembangan mental siswa pun masih pada tahap operasi kongkrit, maka dari itu perlu diupayakan pembelajaran matematika yang sesuai dengan tingkat perkembangan mentalnya siswa.

Upaya mengurangi hal tersebut diperlukan untuk memperbaiki pemahaman siswa melalui pembelajaran yang bermakna agar kendala yang ditemui pada materi lanjutan yang disebabkan oleh kurangnya pemahaman siswa terhadap materi perkalian sebagai materi prasyarat menjadi teratasi. Hal ini dapat dilakukan melalui kegiatan pembelajaran berdasarkan pengetahuan siswa sebelumnya dan pengalamannya. Hal ini sesuai dengan pendapat Gravemeijer (1994), bahwa pembelajaran matematika tidak hanya dilakukan dengan cara mentransfer pengetahuan oleh guru kepada siswa. Siswa perlu diberi kesempatan dan dibimbing untuk menemukan konsepkonsep matematika dengan menggunakan cara mereka sendiri. Salah satu pendekatan yang 
dapat digunakan dan berorientasi pada pengalaman sehari-hari siswa adalah pendekatan Pendidikan Matematika Realistik (PMR) yang merupakan adaptasi dari pendekatan Realistic Mathematics Education (RME) di Belanda.

Kebermaknaan konsep matematika merupakan salah satu konsep utama dari PMR. Pendekatan PMR telah berlangsung sejak 2001 dan telah banyak digunakan dalam upaya memperbaiki minat siswa, sikap dan hasil belajar (Zulkardi, 2009). Fungsi konteks dalam PMR adalah sebagai titik awal bagi siswa dalam mengembangkan pemahaman terhadap matematika dan sekaligus menggunakan konteks tersebut sebagai sumber aplikasi matematika (Zulkardi \& Putri, 2006). Permasalahan realistik disini mengandung makna bahwa masalah tersebut tidak harus selalu ada di dunia nyata dalam kehidupan sehari-hari. Apabila suatu masalah dapat dibayangkan (imaginable) atau nyata (real) dalam pikiran siswa maka masalah tersebut merupakan masalah realistik (Wijaya,2012).

Pendekatan matematika realistik merupakan pendekatan pembelajaran yang menghubungkan materi pelajaran dengan situasi nyata yang dikenal siswa serta proses konstruksi pengetahuan matematika oleh siswa sendiri. Menurut Wijaya (2012) pendekatan matematika realistik mampu membuat siswa aktif dan guru hanya berperan sebagai fasilitator, motivator, dan pengelola kelas yang dapat menciptakan suasana yang menyenangkan. Akibatnya pendekatan PMR diasumsikan dapat menjadi salah satu solusi yang dapat digunakan dalam pembelajaran untuk mengatasi masalah pemahaman siswa sekolah dasar terhadap operasi hitung perkalian. Hal ini didasarkan dari pendekatan PMR yang lebih menekankan kepada konteks dari setiap permasalahan dan kebermaknaan dari setiap pembelajaran yang sesuai dengan tingkat perkembangan mental siswa sekolah dasar yang masih pada tahap konkrit. Hasil penelitian Munarsih (2008) telah terbukti bahwa dengan menggunakan pendekatan pendidikan matematika realistik (Realistic Matemathic Education) dapat meningkatkan hasil belajar matematika siswa.

Adapun rumusan masalah yang diteliti dalam penelitian ini adalah: (1) Apakah hasil belajar siswa dapat meningkat melalui penerapan pendekatan PMR pada materi operasi hitung perkalian di kelas IV SD Negeri 46 Banda Aceh ?; (2) Bagaimana aktivitas siswa dalam pembelajaran dengan menggunakan pendekatan PMR pada materi operasi hitung perkalian di kelas IV SD Negeri 46 Banda Aceh?; dan (3)Bagaimana respon siswa terhadap pembelajaran yang menggunakan pendekatan PMR pada materi operasi hitung perkalian di kelas IV SD Negeri 46 Banda Aceh? 


\section{METODE}

Jenis penelitian yang digunakan adalah penelitian tindakan kelas (classroom action research). Hal ini berdasarkan masalah yang terjadi di kelas IV SD yang sebagian besar siswa terkendala dengan konsep perkalian. Padahal perkalian merupakan materi esensial dan sudah dipelajari di kelas II SD setelah materi penjumlahan serta materi prasyarat untuk materi yang lain. Namun, siswa selalu terkendala dengan konsep perkalian di materi lanjutan di kelas IV SD berdasarkan hasil jawaban siswa yang diperoleh dari setiap ulangan harian yang telah dilaksanakan, sehingga perlu dilaksanakan PTK untuk penyelesaian permasalahan tersebut, oleh karena Penelitian Tindakan Kelas (PTK) merupakan penelitian yang dilakukan dengan sengaja dan sistematis untuk memperbaiki dan meningkatkan kualitas pembelajaran. Upaya tindakan adalah untuk perbaikan yang dimaksud sebagai pencarian jawaban atas permasalahan yang dialami guru dalam melaksaksanakan tugasnya sehari-hari. Jadi masalah-masalah yang diungkap dan dicarikan jalan keluar dalam penelitian adalah masalah yang benar-benar ada dan dialami oleh guru.

Pada penelitian ini penulis menggunakan penelitian tindakan kelas model Kemmis dan Taggart. Menurut Kemmis dan Taggart (Arikunto, 2010) penelitian tindakan dapat dipandang sebagai suatu siklus yang terdiri dari empat kegiatan pokok, yaitu perencanaan, pelaksanaan tindakan, pengamatan (observasi), dan refleksi. Secara mudah PTK yang dikembangkan oleh Kemmis dan Taggart dapat digambarkan dengan diagram alur berikut ini.

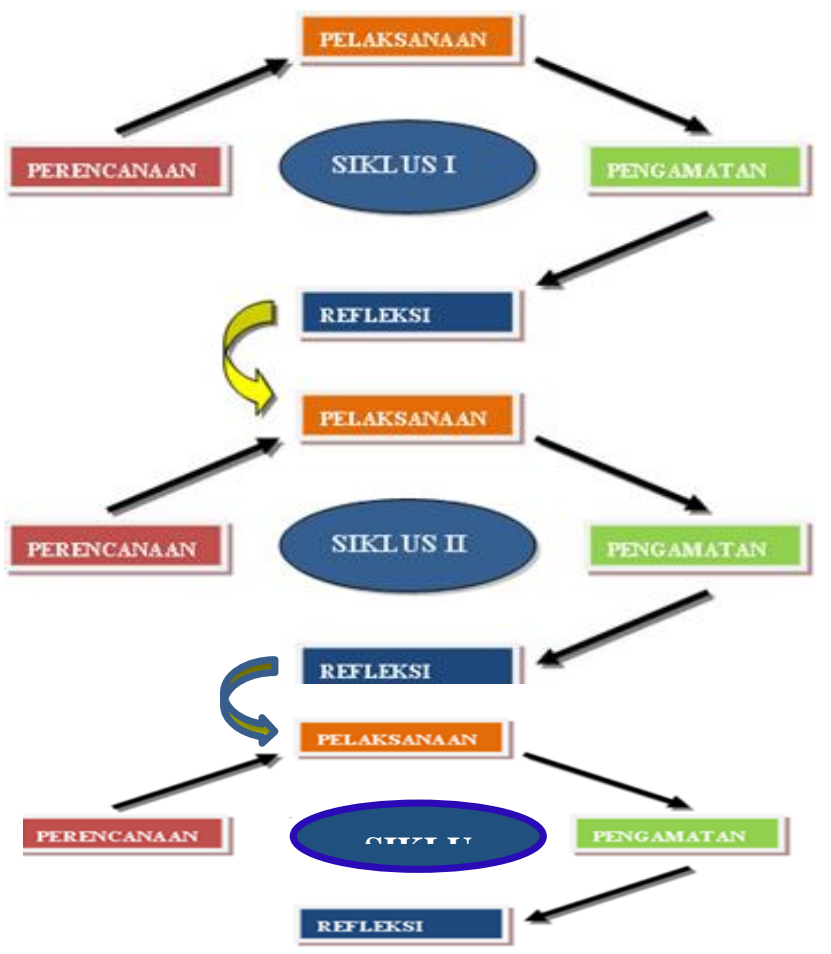

Gambar 1. Alur Pelaksanaan PTK Model Kemmis dan Taggart (Arikunto, 2010) 
Subjek dalam penelitian ini adalah siswa kelas IV SDN 46 Banda Aceh tahun ajaran 2016/2017 yang berjumlah 33 orang terdiri dari 18 orang laki-laki dan 15 orang perempuan. Instrumen penelitian yang digunakan dalam penelitian tindakan kelas ini dibagi dua jenis, yaitu instrumen pembelajaran dan instrumen pengumpulan data. Instrumen pembelajaran adalah RPP dan LKS, sedangkan instrumen pengumpulan data adalah tes, lembar observasi, lembar angket, dan catatan lapangan. Adapun teknik pengumpulan data terdiri dari tes, observasi, dan angket respon siswa yang kemudian dianalisis dengan menggunakan statistik deskriptif.

Proses implementasi setiap siklus dibagi menjadi empat tahapan, yaitu tahap perencanaan, pelaksanaan, pengamatan, dan refleksi. Penyusunan perencanaan didasarkan pada hasil penjajakan refleksi awal. Secara rinci perencanaan mencakup tindakan yang akan dilakukan untuk memperbaiki, meningkatkan atau merubah perilaku dan sikap yang diinginkan sebagai solusi dari permasalahan-permasalahan. Perlu disadari bahwa perencanaan ini bersifat fleksibel dalam arti dapat berubah sesuai dengan kondisi nyata yang ada. Pelaksanaan tindakan menyangkut apa yang dilakukan sebagai upaya perbaikan, peningkatan atau perubahan yang dilaksanakan berpedoman pada rencana tindakan yang hendaknya selalu didasarkan pada pertimbangan teoritik dan empirik agar hasil yang diperoleh berupa peningkatan kinerja dan hasil program yang optimal.

Kegiatan observasi dapat disejajarkan dengan kegiatan pengumpulan data dalam penelitian formal. Dalam kegiatan ini diamati hasil atau dampak dari tindakan yang dilaksanakan atau dikenakan terhadap siswa. Refleksi merupakan kegiatan analisis, sintesis, interpretasi terhadap semua informasi yang diperoleh saat kegiatan tindakan. Dalam kegiatan ini peneliti mengkaji, melihat, dan mempertimbangkan hasil-hasil atau dampak dari tindakan. Setiap informasi yang terkumpul perlu dipelajari kaitan yang satu dengan lainnya dan kaitannya dengan teori atau hasil penelitian yang telah ada dan relevan. Melalui refleksi yang mendalam dapat ditarik kesimpulan apakah dilanjutkan kesiklus selanjutnya atau telah tercapai sebagaiman yang diharapkan.

\section{HASIL DAN PEMBAHASAN}

Hasil pelaksanaan tindakan pada siklus-I sampai siklus-III memperlihatkan adanya peningkatan aktivitas siswa yang diharapkan dalam pembelajaran dan hasil belajar siswa serta tanggapan siswa terhadap pembelajaran juga sudah sangat positif. Hal ini menunjukkan bahwa terjadinya peningkatan kemampuan operasi hitung perkalian siswa melalui penerapan pendekatan pendidikan matematika realistik di kelas IV SD Negeri 46 Banda Aceh. 


\section{Aktivitas Siswa dalam Pembelajaran}

Hasil pengamatan aktivitas siswa selama pembelajaran yang dilakukan oleh satu orang pengamat selama siklus-I sampai siklus-III terus menunjukkan keefektifan, sehingga pada siklus-III semua aktivitas siswa selama pembelajaran dengan pendekatan pendidikan matematika realistik sudah efektif sesuai dengan persentase waktu ideal yang ditetapkan pada setiap aspek pengamatan aktivitas siswa yang berada dalam batas toleransi 5\%. Adapun rekapitulasi keefektifan aktivitas siswa selama pembelajaran dapat dilihat dalam tabel 1.1 berikut.

Tabel 1. Rekapitulasi aktivitas siswa dari siklus-I sampai siklus-III

\begin{tabular}{clccc}
\hline \multirow{2}{*}{ No } & \multicolumn{2}{c}{ Kategori Pengamatan } & \multicolumn{2}{c}{ Efektifitas Berdasarkan Waktu Ideal } \\
\cline { 2 - 5 } 1 & $\begin{array}{l}\text { Memperhatikan penjelasan } \\
\text { guru dan teman }\end{array}$ & $\begin{array}{c}\text { Tidak } \\
\text { Efektif }\end{array}$ & Efektif & Efektif \\
\hline 2 & $\begin{array}{l}\text { Membaca dan memahami } \\
\text { permasalahan kontekstual }\end{array}$ & Efektif & Efektif & Efektif \\
\hline 3 & $\begin{array}{l}\text { Memberikan respon terhadap } \\
\text { permasalahan kontekstual }\end{array}$ & $\begin{array}{c}\text { Tidak } \\
\text { Efektif }\end{array}$ & Tidak Efektif & Efektif \\
\hline 4 & $\begin{array}{l}\text { Mengemukakan ide dalam } \\
\text { menyelesaikan soal }\end{array}$ & $\begin{array}{l}\text { Tidak } \\
\text { Efektif }\end{array}$ & Efektif & Efektif \\
\hline 5 & $\begin{array}{l}\text { Mendiskusikan jawaban } \\
\text { secara berkelompok }\end{array}$ & $\begin{array}{l}\text { Tidak } \\
\text { Efektif }\end{array}$ & Efektif & Efektif \\
\hline 6 & $\begin{array}{l}\text { Menyelesaikan tugas dalam } \\
\text { kelompok }\end{array}$ & Efektif & Efektif & Efektif \\
\hline 7 & $\begin{array}{l}\text { Memberi jawaban dan } \\
\text { tanggapan dalam diskusi kelas }\end{array}$ & $\begin{array}{l}\text { Tidak } \\
\text { Efektif }\end{array}$ & Efektif & Efektif \\
\hline 8 & $\begin{array}{l}\text { Membuat kesimpulan tentang } \\
\text { suatu konsep dan prosedur }\end{array}$ & Efektif & Efektif & Efektif \\
\hline 9 & $\begin{array}{l}\text { Menyelesaikan tugas } \\
\text { individual }\end{array}$ & Efektif & Efektif & Efektif \\
\hline 10 & $\begin{array}{l}\text { Melakukan aktivitas yang } \\
\text { tidak berkaitan dengan } \\
\text { pembelajaran }\end{array}$ & $\begin{array}{l}\text { Tidak } \\
\text { Efektif }\end{array}$ & Tidak Efektif & Efektif \\
\hline
\end{tabular}

Berdasarkan tabel 1 di atas, dapat dilihat bahwa pada siklus-I aktivitas siswa dalam pembelajaran dengan pendekatan pendidikan matematika realistik $40 \%$ efektif, akibatnya aktivitas siswa yang diharapkan belum tercapai sebagaimana yang diharapkan. Pada siklus-II, peneliti lebih menekankan pendekatan pendidikan matematika realistik dengan permasalahanpermasalahan yang open ended agar siswa dapat berpikir terbuka. Harapannya aktivitas siswa yang masih kurang efektif seperti memperhatikan penjelasan guru dan teman, memberikan respon terhadap permasalahan kontekstual, mengemukakan ide dalam menyelesaikan soal, memberi jawaban dan tanggapan dalam diskusi kelas, dan melakukan aktivitas yang tidak berkaitan dengan pembelajaran dapat efektif. 
Hasil aktivitas siswa pada siklus-II sudah menunjukkan peningkatan sehingga $80 \%$ aktivitas siswa dalam pembelajaran efektif. Hal ini diakibatkan oleh pendekatan pendidikan matematika realistik yang setiap permasalahannya sudah berbasis open ended yang menyebabkan aktivitas memperhatikan penjelasan guru dan teman, mengemukakan ide dalam menyelesaikan soal, dan memberi jawaban dan tanggapan dalam diskusi kelas sudah efektif. Siswa sudah tampil lebih berani karena permasalahan-permasalahan open ended sudah membuat siswa berpikir terbuka dan tidak kaku dalam mengembangkan pola pikirnya sesuai dengan minat dan kemampuan masing-masing di dalam kelompok, sehingga semua siswa dalam kelompok dituntut berpikir untuk memecahkan masalah dalam lembar kerja siswa dengan lebih dari satu cara. Hal ini senada dengan pendapat Japa \& Suarjana (2012) menyatakan bahwa proses pembelajaran dirancang untuk menciptakan suasana yang memungkinkan siswa melaksanakan kegiatan belajar matematika. Aktivitas dalam kelompok juga dapat memberikan kesempatan kepada siswa untuk melakukan diskusi, sehingga interaksi siswa dapat terjalin dan terjadinya sharing (petukaran) pendapat.

Hasil aktivitas siswa dalam pembelajaran pada siklus-III sudah sesuai dengan indikator yang diharapkan, dimana 100\% aktivitas siswa sudah efektif. Hasil pengamatan ini menunjukan bahwa $100 \%$ siswa terlibat aktif dalam aktivitasnya selama proses pembelajaran dengan pendekatan pendidikan matematika realistik yang setiap permasalahannya diberikan menuntut siswa berpikir secara terbuka dan dimunculkannya aktivitas yang terdapat dalam model pembelajaran talking stick. Berdasarkan observasi yang telah dilakukan ini terhadap keterlibatan siswa dalam pembelajaran pada siklus-III, maka semua aktivitas siswa dalam pembelajaran sudah efektif dan sesuai dengan indikator pencapaiannya. Rohani (2004) mengatakan bahwa "siswa yang aktif adalah siswa yang aktif dengan anggota badan, membuat sesuatu, bermain ataupun bekerja, ia tidak hanya duduk dan mendengarkan".

\section{Hasil Belajar Siswa}

Sesuai dengan Kriteria Ketuntasan Minimal (KKM) di SD Negeri 46 Banda Aceh yang telah ditetapkan bahwa siswa dikatakan tuntas belajar apabila memiliki daya serap paling sedikit 65, sedangkan ketuntasan belajar secara klasikal tercapai apabila paling sedikit 85\%. Pada siklus-I, capaian ketuntasan hasil hasil belajar siswa hanya mencapai sebesar 33,3\% dan sebesar $66,7 \%$ tidak tuntas. Di siklus-II setelah pendekatan pendidikan matematika realistik lebih ditekankan permasalahannya secara open ended diperoleh hasil belajar siswa sebesar 63,6\% telah tuntas dan sebesar 36,4\% tidak tuntas. Pada siklus-III setelah ditambahkan aktivitas baru atas pertimbangan untuk mengaktifkan siswa yaitu dengan adanya aktivitas yang terdapat 
dalam model pembelajaran talking stick dalam penerapan pendekatan pendidikan matematika realistik yang permasalahannya berbasis open ended diperoleh hasil belajar siswa sebesar 96,97\% tuntas dan sebesar 3,03\% tidak tuntas. Berdasarkan ketuntasan secara klasikal, maka hasil belajar siswa pada siklus-III telah mencapai ketuntasan secara klasikal. Adapun hasil belajar siswa selama siklus-I sampai siklus-III dapat dilihat dari sajian diagram batang berikut.

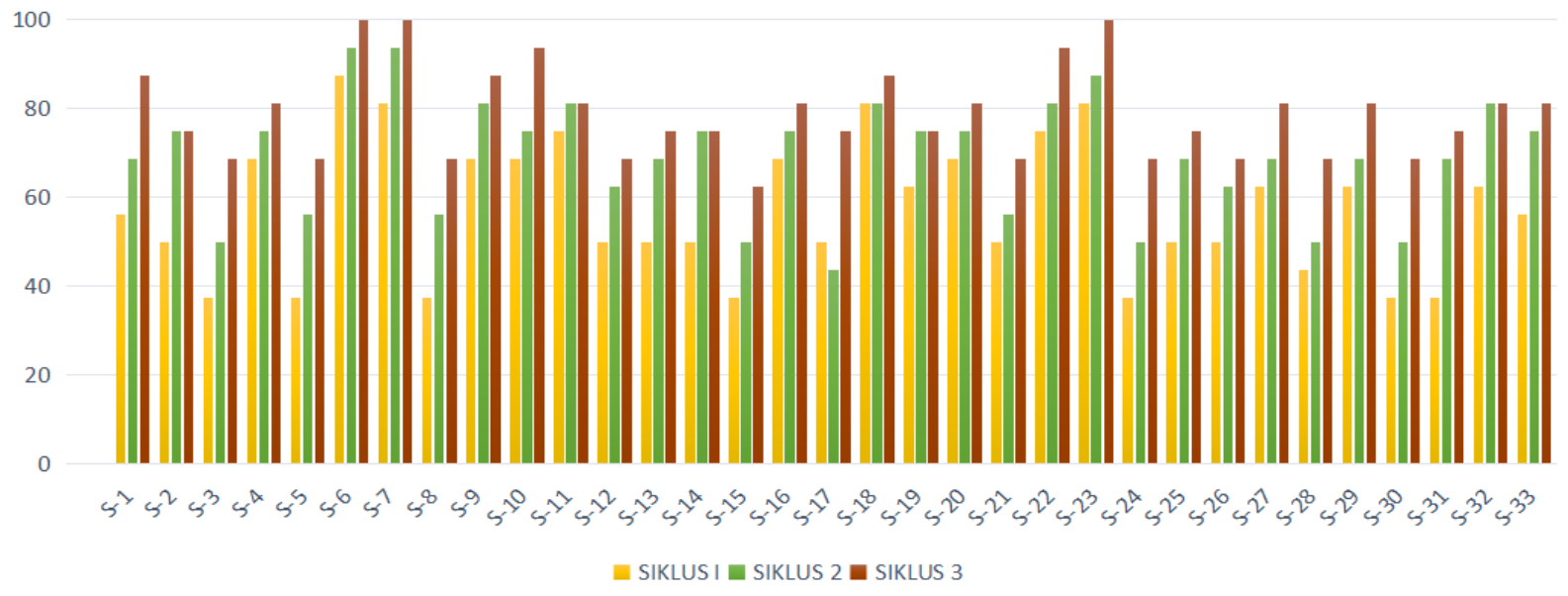

Gambar 2. Hasil tes formatif hasil belajar siswa

Berdasarkan gambar 2 di atas dapat dilihat bahwa peningkatan hasil belajar dari setiap siklus dapat terlihat dengan jelas, sehingga pada siklus-III ketuntasan hasil belajar siswa sudah mencapai ketuntasan secara klasikal. Hal ini terjadi karena setiap siklus guru selalu memberikan tindakan-tindakan yang dapat membantu pemahaman siswa menjadi lebih baik, sehingga terlihat jelas berbanding lurus antara hasil belajar dengan aktivitas siswa pada setiap siklus. Purwanto (1994) menyatakan bahwa hasil belajar seringkali digunakan sebagai ukuran untuk mengetahui seberapa jauh seseorang menguasai bahan yang telah diajarkan. Peningkatan hasil belajar siswa setiap siklus juga dapat dilihat dalam diagram garis berikut.

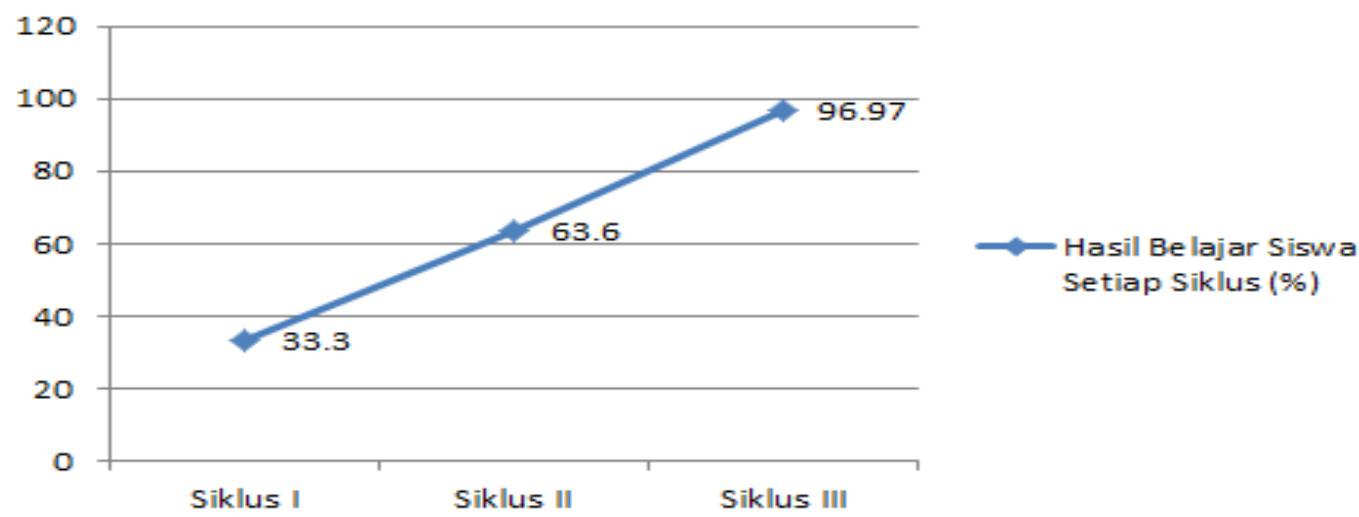

Gambar 3. Grafik Ketuntasan Hasil Belajar Setiap Siklus 
Keberhasilan berdasarkan gambar 3 tidak terlepas dari bimbingan guru setiap siklus ditingkatkan dan pendekatan pendidikan matematika realistik yang digunakan. Karena melalui pendekatan pendidikan matematika realistik siswa dapat belajar secara optimal. Wijaya (2012) mengatakan bahwa suatu pengetahuan akan menjadi bermakna bagi siswa jika proses pembelajarannya dilaksanakan dalam suatu konteks atau pembelajaran menggunakan masalah realistik. Adapun salah satu bentuk iceberg pada konsep perkalian dengan pendekatan pendidikan matematika realistik yang telah dilaksanakan sebagai berikut.

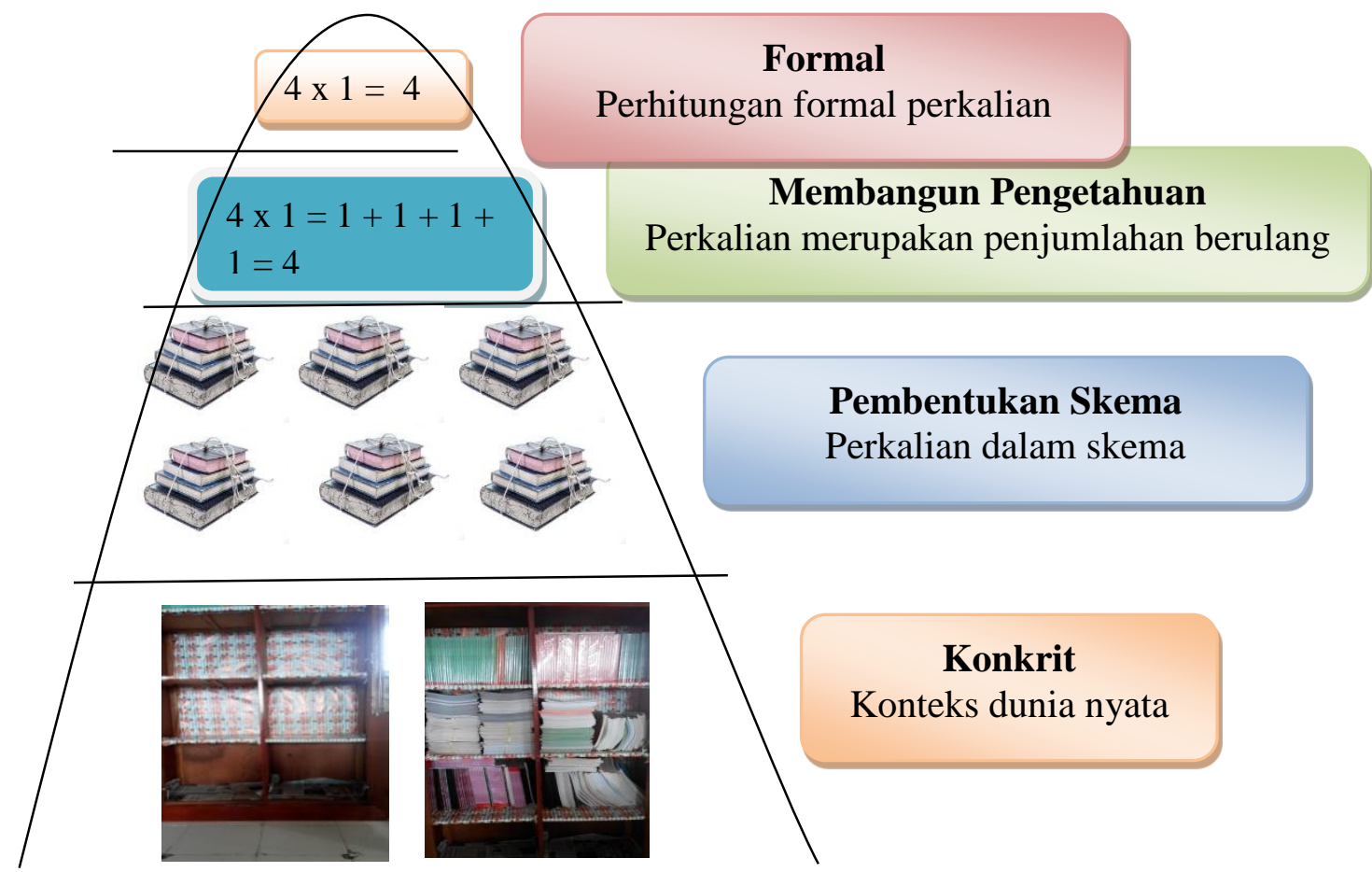

Gambar 4. Iceberg perkalian bilangan satuan

\section{Respon Siswa Terhadap Pembelajaran}

Angket respon siswa diberikan kepada setiap siswa pada akhir pertemuan setiap siklus yaitu setelah siswa menyelesaikan tes akhir siklus. Angket respon siswa bertujuan untuk mengetahui perasaan siswa, minat siswa dan pendapat siswa mengenai pelaksanaan pembelajaran dengan menggunakan pendekatan pendidikan matematika realistik pada materi operasi hitung perkalian.

Siswa sangat tertarik belajar dengan pendekatan matematika realistik, tidak hanya pada materi perkalian tetapi juga pada materi yang lainnya. Hal ini sesuai dengan pernyataan siswa terhadap pembelajaran dengan pendekatan pendidikan matematika realistik dalam kategori 
positif dan sangat positif. Hasil respon siswa terhadap pembelajaran di setiap siklus dapat dilihat dalam diagram batang berikut.

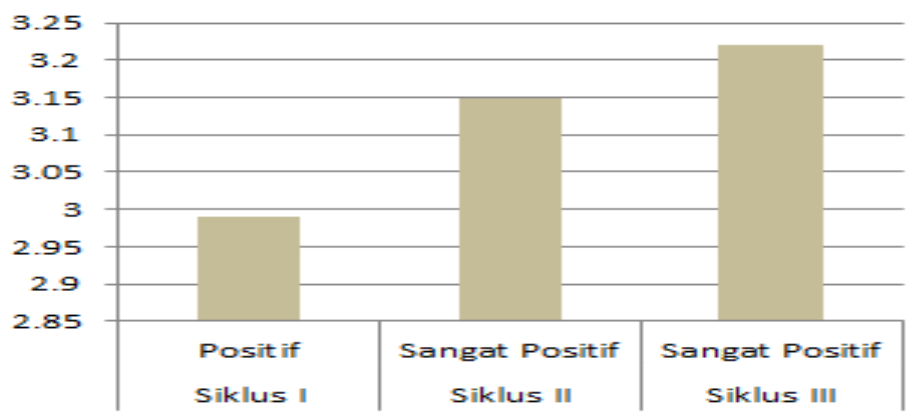

Gambar 5. Hasil Respon Siswa Terhadap Pembelajaran Setiap Siklus

Peryataan siswa dalam kategori positif dan sangat positif berdasarkan gambar 5 di atas tidak terlepas dari rasa senang siswa terhadap pembelajaran. Artinya pembelajaran dengan pendekatan pendidikan matematika realistik ini menimbulkan rasa puas bagi siswa, karena pembelajaran ini merupakan pembelajaran yang baru bagi mereka seperti materi pelajaran, LKS, tes hasil belajar, suasana pembelajaran di kelas dan cara guru mengajar. Rasa senang siswa juga disebabkan oleh adanya konteks sebagai starting point di setiap siklus.

Adapun pembelajaran dengan pendekatan PMR yang mampu meningkatkan keaktifan siswa, ketuntasan hasil belajar, dan respon siswa yang sangat positif adalah pembelajaran dengan pendekatan PMR yang memiliki ciri-ciri sebagai berikut: (1) Penyajian kelas dilakukan dengan pendekatan PMR yang permasalahannya lebih ditekannkan secara open ended dan adanya aktivitas talking stick di akhir aktivitas diskusi kelompok, (2) Penggunaan media tidak dibatasi, (3) Keanggotaan kelompok dibuat secara heterogen, (4) Siswa diberikan keleluasaan untuk menggunakan cara dan bahasa yang mereka inginkan, (5) Siswa didorong menyajikan tugasnya dalam bentuk laporan penyelesaian tugas.

\section{SIMPULAN}

Berdasarkan hasil kegiatan pembelajaran yang telah dilakukan selama tiga tahap, yaitu siklus-I, siklus-II, dan siklus-III, serta berdasarkan hasil analisis dan pembahasan yang telah diuraikan, maka dapat disimpulkan sebagai berikut: (1) Aktivitas siswa yang diharapkan dalam pembelajaran terdapat peningkatan dengan menggunakan pendekatan PMR pada materi operasi hitung perkalian di kelas IV SD Negeri 46 Banda Aceh. Siklus-I terdapat $40 \%$ aktivitas siswa yang aktif, siklus-II terdapat $80 \%$ aktivitas siswa yang aktif, dan pada siklus-III 100\% aktivitas siswa aktif. (2) Terdapat peningkatan kemampuan operasi hitung perkalian siswa melalui 
penerapan pendekatan PMR di kelas IV SD Negeri 46 Banda Aceh. Siklus-I terdapat 33,3\% tuntas dan $66,7 \%$ tidak tuntas, siklus-II terdapat $63,6 \%$ tuntas dan $36,4 \%$ tidak tuntas, dan siklus-III terdapat 96,97\% tuntas dan 3,03\% tidak tuntas. (3) Terdapat respon siswa yang sangat positif terhadap pembelajaran dengan menggunakan pendekatan PMR pada materi operasi hitung perkalian di kelas IV SD Negeri 46 Banda Aceh. Respon siswa pada siklus-I dalam kategori positif dan pada siklus-II serta siklus-III berada dalam kategori sangat positif.

\section{DAFTAR PUSTAKA}

Arikunto, S. (2010). Prosedur penelitian suatu pendekatan praktik. Jakarta: Rineka Cipta.

Depdiknas. (2006). Kurikulum tingkat satuan pendidikan (KTSP). Jakarta: Departemen Pendidikan Nasional.

Gravemeijer, K. (1994). Developing realistic mathematics education. Utrecht: Freudenthal Institute.

Heruman. (2007). Model pembelajaran matematika di sekolah dasar. Bandung: Remaja Rosdakarya.

Hudojo, H. (1990). Strategi belajar mengajar. Malang: IKIP Malang.

Munarsih, A. (2008). Upaya penigkatan hasil belajar matematika melalui pendekatan Realistic Mathematic Education (RME). Tesis, tidak diterbitkan, UMS Surakarta.

Muslimin. (2012). Desain pembelajaran pengurangan bilangan bulat melalui permainan tradisional congklak berbasis Pendidikan Matematika Realistik Indonesia di kelas IV Sekolah Dasar, Kreano, 3 (2), 100-112.

Nilakusumawati, D. E. (2014). Kajian efektivitas penerapan metode ringkas dalam perkalian susun. Jurnal Matematika, 4(2), 112-129.

Purwanto, N. (1994). Prinsip-prinsip dan teknik evaluasi pengajaran pendidikan. Bandung: Remaja Rosdakarya

Rohani, A. (2004). Pengelolaan pengajaran. Jakarta: Rineka Cipta.

Saahi, M. N,. Ismaimuza, D., \& Idris, M. (2015). Meningkatkan hasil belajar siswa pada perkalian bilangan bulat di kelas IV SDN 1 Nambo dengan menggunakan metode tutor sebaya. Jurnal Kreatif Tadulako, 4 (12), 38-50.

Wardhani. (2010). Implikasi karakteristik matematika dalam pencapaian tujuan mata pelajaran matematika di SMP/MTs. Yogyakarta: PPPPTK Matematika.

Wijaya, A. (2012). Pendidikan matematika realistik: Suatu alternatif pendekatan pembelajaran matematika. Yogyakarta: Graha Ilmu.

Zulkardi. (2009). The "P" in PMRI: Progress and problems. ICMA Mathematic Education. Yogyakarta: IndoMs.

Zulkardi \& Ilma, R. (2006). Mendesain sendiri Soal kontekstual matematika. Prosiding Konferensi Nasional Matematika XIII. Semarang: IndoMS 